\title{
The Quality of Teaching and Learning towards the Satisfaction among the University Students
}

\author{
Suarman ${ }^{1}$, Zahara Aziz ${ }^{2}$ \& Ruhizan Mohammad Yasin ${ }^{2}$ \\ ${ }^{1}$ Faculty of Education, University of Riau, Pekanbaru, Indonesia \\ ${ }^{2}$ Faculty of Education, Universiti Kebangsaan Malaysia, Bangi, Malaysia \\ Correspondence: Miharty, Faculty of Education, University of Riau, Pekanbaru, Indonesia. E-mail: \\ cun_unri@yahoo.co.id
}

\author{
Received: August 1, 2013 Accepted: August 16, 2013 Online Published: August 30, 2013 \\ doi:10.5539/ass.v9n12p252 URL: http://dx.doi.org/10.5539/ass.v9n12p252
}

\begin{abstract}
The aim of this study is to examine the relationship between the students' perception of the quality of teaching and learning and their satisfaction in a great university in Indonesia, which was very important in the effort of upgrading the quality of higher education. A survey research involving the sample of 387 students was conducted. The research instruments of the study regarding the quality of teaching and learning consisted of aspects such as the courses, lecturers' motivation, instructional design, relationship among students, relationship between students and lecturers, task assignment, lecturers' efficiency, evaluation, obstacles and restraints, as well as the instrument for measuring students' satisfaction. The research findings were analyzed using the descriptive statistics and inferential statistics such as T-Test, correlation, and regression. The findings showed that students' perception of the quality of teaching and learning was at the moderate level, and students' satisfaction was also at the moderate level. Based on the inferential statistics, it was indicated that there was a difference in the perception of the quality of teaching and learning concerning the gender, study period, and field of study. Similarly, there was also a difference in students' satisfaction based on gender, study period, and field of study. The correlation analysis showed that students' perception of the quality of teaching and learning had a positive relationship with their satisfaction, whereas the results of the regression test presented the existence of the 9 dimensions of positive contributions of the quality of teaching and learning in relation to students' satisfaction. The study recommendation is that the university find out about students' needs in the teaching and learning processes, including the physical needs or methods of generating a better relationship between the students and university as well as among students in order to enhance the quality of higher education. Thus, the main implication of this study regarding the education discipline was the discovery of the status of the quality of teaching and learning in an educational institution as the principal factor of the increment in students' satisfaction.
\end{abstract}

Keywords: university students, teaching quality, learning quality, students'satisfaction

\section{Introduction}

The institution of higher education that has effective leadership, instructors who possess high knowledge and professionalism, teaching and learning facilities, quality students, and relevant curriculum will be more competitive in encountering the global competition. This aptitude can be measured in the aspect of the ability of the higher education system to produce the graduates who possess the qualities as aspired in the National Philosophy of Education, employability according to the industrial demands, capability to achieve success in entrepreneurship, and potentiality in giving good contributions to the society. Effective leadership in administering the institution of higher education is crucial to ensure that the implementation and accomplishment of the strategic objectives of the institution are achieved. High caliber instructors who own high knowledge are able to educate and produce quality students. This strategic principal element is founded with the aim of ensuring all students of the higher education to gain benefits from the experience of quality learning which is in line with requirements of the individual, economy, and society.

The quality of teaching and learning at the institutions of higher education is one of the things to be considered by students when entering college, since the quality of teaching and learning happens to be one of the instruments influencing students' satisfaction. A higher education system which is developed and excellent in 
quality is in the hope and expectation of all of the students who are accepted by the college. One of the indicators of the best institution of higher education is its teaching and learning quality. Robiah Sidin (2000) stressed that the key to the development of higher education so far is the improvement in the quality of teaching and learning. Students as the customers hope to gain satisfaction after participating in the teaching and learning sessions. According to Greiner (2000), the quality of service and quality of teaching are related to the students' satisfactions that function as the customers of the institution. The components of the quality of teaching and learning encompass the entire aspects involved in the implementation of teaching and learning in the effort of accomplishing teaching objectives. One of the measurement indicators of the quality teaching and learning is the ability to achieve the instructional goals successfully. As suggested by Harvey and Green (1993), the main principle in measuring the quality of teaching and learning in a university is the evaluation of the institution in terms of its approach in accomplishing objectives. It can be concluded that the more able the university in accomplishing its goals, the more quality it will have, whereas the institutions which are unable to achieve their objective successfully will be considered to have poor quality. The achievement of objectives is the primary indicator of the quality of teaching and learning as well as students' satisfaction, since satisfaction is the effect produced from the participation in teaching and learning. Oliver (1997) defined customers' satisfaction as the feedback regarding the fulfillment of the customers' requirements. Holford and Patkar (2003) in Handoyos (2006) stated that there are five items of overall students' satisfaction comprising the quality of the facilities, quality of the learning process, quality of the service, quality of the curriculum, and quality of the instructional implementation.

\section{Statement of the Problem}

The increasing enrolment of students in various disciplines requires numerous instructors who are expert in their specialized fields. The institutions of higher education should be more competitive, conforming to the government policy and aspiration of transforming our country into the regional world-class centre of excellence in education. The key to the development of higher education today is the enhancement in the quality of teaching and learning (Robiah Sidin, 2000).

Students are of the main customers of an institution of higher education who need to be prioritized, considering their individual needs which have to be fulfilled. They hope for the exciting learning experience and quality teaching and learning processes. Therefore, students own the rights to receive quality education, and it is the responsibility of the faculty or learning centre to ensure the quality of the courses and programs offered. Despite the significance mentioned, there are still not much effort contributed in investigating the relationship between the quality of teaching and learning and students' satisfaction (Guolla, 1999).

A research needs to be conducted to observe the impact of the quality of teaching and learning on students' satisfaction throughout their time spent enrolling in their study programs. The objectives of the study were to (1) review on students' perception of the quality of teaching and learning throughout their enrolment in the study program in the institution of higher education, (2) investigate the relationship between the quality of teaching and learning and students' satisfaction with the study program, (3) determine to what extent the quality of teaching and learning contributes to students' satisfaction with the study program.

\section{Literature Review}

\subsection{The Quality of Teaching and Learning}

Every student enrolled in the institution of higher education dreams for a better quality of teaching and learning, and the university which provides quality teaching and learning is something they would be proud to have. The quality will also enable the college to motivate the students better than the other institutions do. Hence, it is very important for the higher education to prioritize the quality of teaching and learning. Chong \& Crowther (2005) focused more on the quality of higher education in relation to students which encompasses what is learnt by the students, what is understood by them, what tasks they can perform, and the extent of competence the students acquire as the result of the interaction between the students and lecturers. The quality of higher education has to be related to the practice of knowledge and learning experience obtained by the students. It can be concluded that the components contained in the teaching and learning processes are the main factors determining the quality of teaching; which consists of the lecturer (motivation, competence, the technique of building rapport with the students), teaching tools (courses, syllabus, media, teaching methods), students (students' competence, relationship among students), and instructional implementation (explanation on lecture materials, task assignment, evaluation, as well as restraints in teaching). In details, the components of the quality of teaching and learning are elaborated by (Marsh 1990; Toland \& De Ayala, 2005; Gursoy \& Umbreit, 2005; Oxford Brookes University, 2005) which entails the nine components altogether, which are the 1) courses, 2) lecturers' 
motivation, 3) instructional design, 4) relationship among students, 5) relationship between the students and lecturers, 6) assignment, 7) lecturers' competence, 8) obstacles and constraints, and 9) evaluation.

\subsection{Students'Satisfaction}

Satisfaction is the impact of the processes which have taken place during the teaching and learning sessions participated by the students. Wilkie (1990) defined customer's satisfaction as the emotional response to the evaluation of the affairs of consuming a product or receiving a service. The satisfaction with the quality of teaching and learning is the students' emotional reaction after attending lectures. The quality of teaching and learning is associated with students' satisfaction. Likewise, Ramsden (1991), Rowley (1996), and Stringer and Irwing (1998), in their studies, reported that there was a relationship between the learning quality and students' perception of the teaching quality. Henning et al. (2001) discovered that the quality of teaching and students' emotional commitment to the institution were important to maintain the students' loyalty.

The objective of the study was to determine the students' perception of the quality of teaching and learning at the university. The research also aimed to investigate the relationship between the students' perception of the quality of teaching and learning and their satisfaction. In the current study, the researcher also sought to determine to what extent the students' perception of the quality of teaching and learning contribute to their satisfaction with the university. Handoyo (2006) proposed that there are five items of overall students' satisfaction which comprise the quality of the facilities, quality of the learning process, quality of service, quality of curriculum, and quality of instructional design.

\section{Purpose of the Study}

This research intended to determine the students' satisfaction with the quality of the teaching and learning sessions conducted by the lecturers at the university. The study also aimed to identify the level of students' satisfaction and the level of the instructors' teaching quality in the aspects of the courses, lecturers' motivation, instructional design, relationship among students, relationship between the students and lectures, task assignment, lecturers' efficiency, evaluation, as well as obstacles and restraints. In addition, the research was also conducted with the purpose of investigating the relationship between the nine aspects of the quality of the instructors' teaching and students' satisfaction.

\section{Methodology}

This study was carried out using the survey method on students' satisfaction with the quality of teaching and learning at the university. Mohd Majid (2000) claimed that the survey method was used with the aim to measure a variable which is related to a phenomenon that occurs, without having to argue why the variable exists. The pilot study showed that the value of Cronbach Alpha was between 0.82 and 0.86 indicating the reliability of the instrument was at acceptable level. The study employed the descriptive approach which described the students' perception of the quality of teaching and learning and their satisfaction. According to Leedy and Ormod (2001), a descriptive research aims to explain the occurring scenario where the situation really happens in the school which has been chosen as the research subject. The research sample consisted of 387 students who were selected using the cluster random sampling at each of the faculties of the university chosen. The research instruments were constructed based on the previous studies conducted by (Marsh 1990; Toland \& De Ayala 2005; Gursoy \& Umbreit 2005; Lin et al. 1994; Flinders University 2001; Oxford Brookes University 2005) which covered the nine aspects, such as the 1) courses, 2) lecturers' motivation, 3) instructional design, 4) relationship among students, 5) relationship between the students and lecturers, 6) assignment, 7) lecturers' competence, 8) obstacles and constraints, and 9) evaluation. The dependent variable in this research was the satisfaction which involved the five items of overall students' satisfaction, which were the quality of the facilities, quality of the learning process, quality of service, quality of curriculum, and quality of instructional design.

\section{Findings and Discussion}

Based on Table 1, the research findings present the nine components of the teaching quality and the students' satisfaction which was at the moderate level in general. This implies that the students felt that the quality of teaching and learning at the university was still dissatisfactory. These findings are consistent with the research done by Saedah Siraj (2005), and Gusti and Desak (2008). Circumstantially, students' views on the teaching quality and their satisfaction were as follows. 1) Students' perception of the courses was at the low level. 2) Students' perception of the lecturers' motivation was at the moderate level . 3) Students' perception of the instructional design was at the moderate level. 4) Students' perception of the relationship among the students was at the moderate level. 5) students' perception of their relationship with the lecturers was at the moderate level . 6) students' perception of the lecturers' knowledge efficiency was at the moderate level . 7) students' perception of 
the evaluation was at the moderate level . 8) students' perception of the assignment was at the moderate level. 9) students' perception of the barriers and constraints was at the moderate level .

Students' satisfaction was also at the moderate level in general. This shows that the students at the university had not yet achieved the high satisfaction which was sufficient with their requirements that were expected to be fulfilled. These findings contradict the statement by Made (2007) reporting that the students' satisfaction with the educational service was generally better.

Table 1. Students' perception of the quality of teaching and learning in the university

\begin{tabular}{llll}
\hline Variable & Mean & Stdv & Level \\
\hline Courses & 2.15 & .09 & Low \\
Lecturer's motivation & 2.78 & .95 & Moderate \\
Instructional design & 2.89 & 1.0 & Moderate \\
Relationship among students & 2.22 & 1.0 & Moderate \\
Relationship with the lecturers & 2.85 & .99 & Moderate \\
Task assignment & 3.08 & .95 & Moderate \\
Lecturers' efficiency & 2.64 & 1.0 & Moderate \\
Evaluation & 3.14 & .94 & Moderate \\
Obstacles and restraints & 2.72 & 1.03 & Moderate \\
Students' satisfaction & 3.28 & .51 & Moderate \\
\hline
\end{tabular}

Table 2 contains the analysis results of the relationship between the quality of teaching and learning and students' satisfaction. The results indicate that all of the variables of the quality of teaching and learning had a significant relationship with the students' satisfaction. This is in line with the studies conducted by Ali Kara (2004) and Sevgi Ozgungor (2009). The variables which had a significant relationship with the students' satisfaction that were at the low level consisted of the 1) courses, 2) instructional design, 3) relationship among students, 4) lecturers' competence, and 5) barriers and constraints, while the variables which had a significant relationship with the students' satisfaction that were at the moderate level comprised the 1) lecturers' motivation, 2) relationship between the lecturers and students, 3) assignments, and 4) evaluation.

Table 2. The relationship between the quality of teaching and learning and the students' satisfaction with the university

\begin{tabular}{llll}
\hline Variable & $\mathbf{r}$ & Sig & Correlation \\
\hline Courses & $.206^{* *}$ & .000 & Low \\
Lecturers' Motivation & $.312^{* *}$ & .000 & Moderate \\
Instructional Design & $.161^{* *}$ & .001 & Low \\
Relationship among Students & $.174^{* *}$ & .001 & Low \\
Relationship with the Lecturers & $.325^{* *}$ & .000 & Moderate \\
Lecturers' Efficiency & $.244^{* *}$ & .000 & Low \\
Task Assignment & $.539^{* *}$ & .000 & Moderate \\
Examination and Evaluation & $.383^{* *}$ & .000 & Moderate \\
Barriers and Constraints & $.164^{* *}$ & .000 & Low \\
\hline
\end{tabular}

Figure 1 describes the influence of the quality of teaching and learning on the satisfaction of the university students. The regression analysis involved the use of AMOS 18 to find out how intense the influence of the quality of teaching and learning on the students' satisfaction was. The analysis results show that the model tested fit the Chi Square value of 317.671 with $\mathrm{P}=.000$. This denotes that the model fit the data, yet the value of $\mathrm{GFI}=8.26<0.9$, AGFI $=.734<.0 .9, \mathrm{TLI}=.103<0.9$ and $\mathrm{RMSEA}=.142>0.08$. Based on the analysis of the 
confirmatory factors done on the exogenous variables, it is understood that the model has not yet met the criteria of the goodness of fit specified. The test value of the goodness of fit with $\chi^{2}$ was as big as 317.671 with the probability of $0.00<0.05$, indicating that there was no difference between the experimented model and the observational data. The results of the measure of conformity of the other models were at the poor level. Therefore, the conformity of the predicted model with the observational values of the exogenous variable has not met the requirements set.

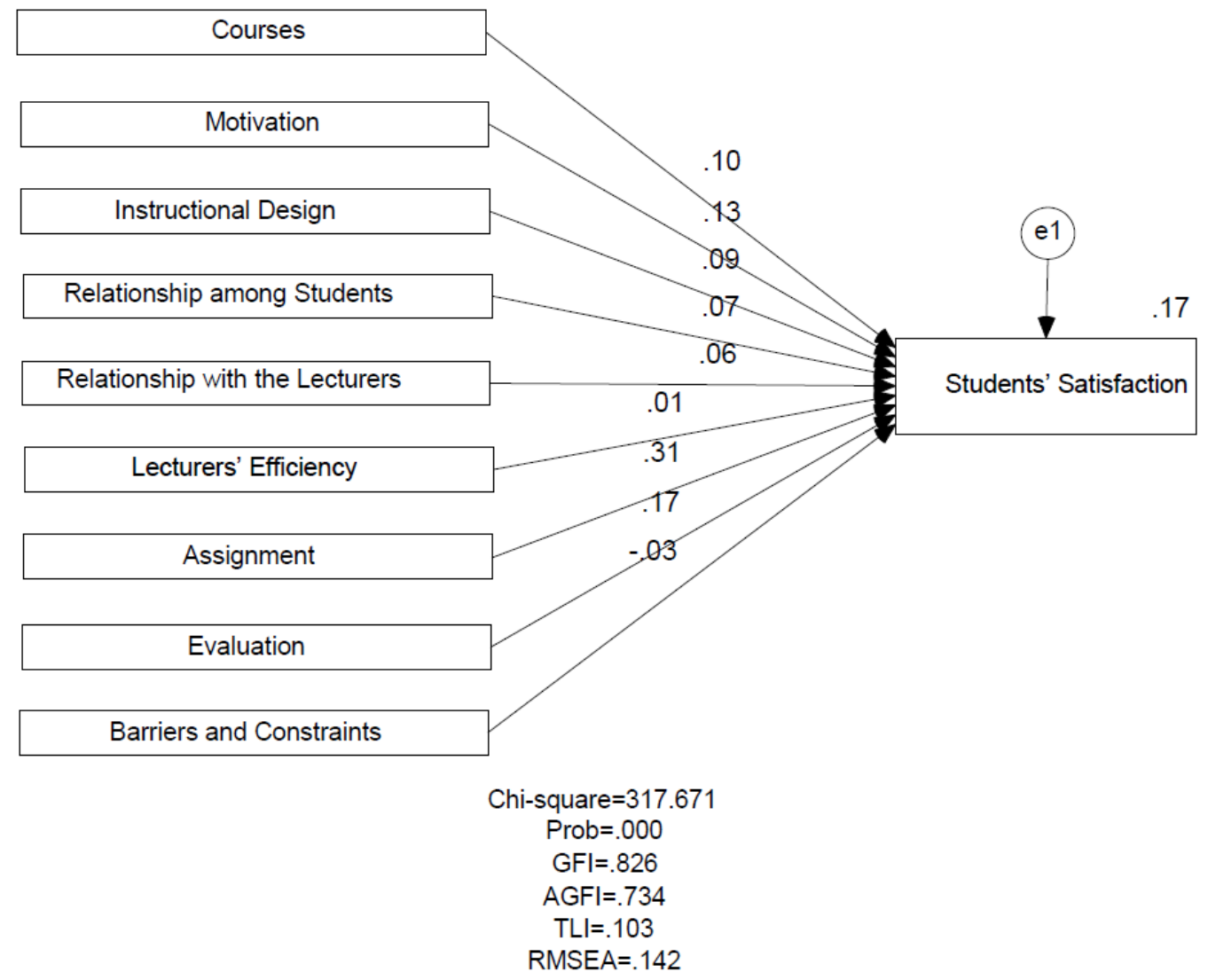

Figure 1. The contributions of the nine domains of students' perception of the quality of teaching and learning to the satisfaction of Riau university students

Based on the Standardized Regression Weights analysis tabulated in Table 3, the influence of the nine components of the students' perception on the quality of teaching and learning on students' satisfaction involved 1) students' perception of the course which contributed $=.100(10 \%)$ to students' satisfaction, 2) students' perception of the lecturers' motivation which contributed $=.132(13.2 \%)$ to students' satisfaction, 3) students' perception of the instructional design which contributed $=.087(8.7 \%)$ to students' satisfaction, 4) students' perception of the relationship among students which contributed $065(6.5 \%)$ to students' satisfaction , 5) students' perception of the relationship between the lecturers and the students which contributed $=.014(1.4 \%), 6)$ students' perception of the lecturers' efficiency which contributed $\left.=.=.309^{* * *}(30.9 \%), 7\right)$ students' perception of the evaluation which contributed $=.-026(2.6 \%), 8)$ students' perception of the barriers and constraints which contributed $=.064(6.4 \%)$ to students' satisfaction . 
Table 3. The standardized regression weights analysis results of the influence of the variable of the teaching quality on the students' satisfaction

\begin{tabular}{llll}
\hline & & & Estimate \\
\hline Students' Satisfaction & $<---$ & Courses & .100 \\
Students' Satisfaction & $<--$ & Lecturers' Motivation & .132 \\
Students' Satisfaction & $<--$ & Instructional Design & .087 \\
Students' Satisfaction & $<---$ & Relationship among Students & .065 \\
Students' Satisfaction & $<--$ & Relationship with the Lecturers & .014 \\
Students' Satisfaction & $<---$ & Lecturer's Efficiency & .309 \\
Students' Satisfaction & $<--$ & Assignment & .168 \\
Students' Satisfaction & $<---$ & Evaluation & -.026 \\
Students' Satisfaction & $<---$ & Barriers and Constraints & .064 \\
\hline
\end{tabular}

Table 4 presents the Squared Multiple Correlations analysis of the influence of the nine components of students' perception of teaching and learning on the students' satisfaction comprising the 1) courses, 2) lecturers' motivation, 3) instructional design, 4) relationship among students, 5) relationship between the students and lecturers, 6) assignment, 7) lecturers' competence, 8) obstacles and constraints, and 9) evaluation, which altogether contributed $=.168$ to the satisfaction of the students. This shows that the nine components of the students' perception on the quality of teaching and learning gave the contribution of $16.8 \%$ in total.

Table 4. The squared multiple correlations analysis of the influence of the nine components of students' perception of teaching and learning on the students' satisfaction in total

Estimate

\begin{tabular}{lll}
\hline Students' & The Nine Components of Students' Perception on Teaching and \\
Satisfaction & $<---\begin{array}{l}\text { Learning } \\
\text { Le8 }\end{array}$
\end{tabular}

The overall findings of the study denotes that students' perception of the quality teaching and learning were at the moderate level, implying that the quality of teaching and learning in the students' view was good. The students evaluated the teaching and learning processes at university as able to fulfill their requirements, yet their hope of receiving the instructions which are higher in quality has not yet accomplished. This findings differ with the findings of a research done at the Faculty of Mathematics and Natural Sciences of the University of Udayana Bali which discovered that the quality of service given by the university to the students must be enhanced since there was a really high imbalance between the quality of service expected by the students and the quality of service which was actually received by them. Gusti and Desak (2008) and Zulkiflee (2002) in their research found out that the factors which influence the students' attitude are the teachers, curriculum, purposes, instructional periods, facilities, and tools. All of the components of teaching and learning are part of the quality of teaching and learning, making them potent in influencing students' positive attitudes and satisfaction.

The purpose of the evaluation of the quality of teaching and learning was to provide the lecturers and universities with the views on the extent to which the quality of the educational service can be given so that the suggestions can be accounted as the guidelines in improving the teaching and learning processes conducted by the instructors. This is parallel with Rowley (1996) who asserted that the evaluation of the quality of teaching and learning are beneficial in helping teachers to enhance their teaching quality as well as functioning as the direct measure of the students' satisfaction throughout their higher education period. According to Barnard (1999), there is a positive correlation between the Total Quality Management (TQM) in the teaching and learning processes and the students' perception of the effectiveness of the instructions delivered by the instructors.

The findings in the research done by I Made (2007) on the students' satisfaction with the quality of the educational service indicated that students generally expressed better satisfaction, instead they were rather dissatisfied with the high cost of higher education and the non-optimal use of the instructional media. On the 
same note, Aldridge and Rowley (1998) stated that it was clear that from the students' point of view the quality education provides better learning opportunities and the level of satisfaction and dissatisfaction largely influences the students' success or failure. Deshields et al. (2005) and Palacio et al. (2002) who have carried out research projects on the university students in Spain found that the image of the university influenced the satisfaction of the students with the university. The image of a university was determined by the quality of the service and administration performed by the university as well as its ability in producing competent graduates. The university with a better image paid attention to the students' needs and organized the educational programs which are appropriate with the students' requirements in the future career world. Henning et al. (2001) affirmed that the teaching quality and students' emotional commitment to the institution are crucial in maintaining students' loyalty.

The findings of this study indicate that there was a positive relationship between the students' perception of the quality of teaching and learning and the satisfaction of the students. This implies that the higher the quality of teaching and learning is, the higher the students' satisfaction with the university will be. On the contrary, if the quality of teaching and learning is poor, the students' satisfaction will also be reduced. Ali Kara (2004) in his research at the College of Business Administration, Pennsylvania State University discovered that the relationship between the college students' knowledge and their satisfaction was positive and significant. SevgiOzgungor (2009) proposed that there is a significant relationship between the self-efficacy and students' evaluation, since the self-efficacy is closely-related to the good instruction and the capability of teachers in organizing the teaching using clear instructions.

The result of the analysis using AMOS on the influence of the quality of teaching and learning on the students' satisfaction was $16.8 \%$, and the rest was determined by other factors. A research by Hill (1995) showed that the primary customers of the university were the students and the higher education institutions were increasingly aware of their status in the industry service, urging them to give extra attention in fulfilling students' desire and needs (Elliot \& Shin, 2002). Students' satisfaction is the overall impact of the teaching and learning, not only the knowledge earned by the students (Wiers-Jenssen, Stensaker \& Grogaard, 2002). Just as suggested by Elliott and Shin (2002), satisfaction is the outcome variable which is appropriate to investigate since it benefits the students in terms of the courses, motivational improvement, lower rates of issues, and better instruction. Overall, it can be concluded that the quality of teaching and learning gives positive and significant contribution to the enhancement of students' satisfaction.

\section{Implication}

One of the principal factors in upgrading the university is the enhancement in the quality of teaching and learning. Based on the findings of the study, overall, the evaluation of the quality of teaching and learning was at the moderate level. This implies that the quality of teaching received by the students was not at satisfactory level, since the students evaluated the teaching and learning processes at the university as still being unable to meet their hope and expectation. This finding provides the information for the lecturers to enhance their teaching quality especially in the aspects of the courses and their relationship with the students. Various strategies can be applied by the lecturers in the effort of producing good quality of instruction.

In addition, the findings of the study in general shows that students' satisfaction with the university was at the moderate level. This indicates that the university students have not gained the high satisfaction which is sufficient to meet their requirements. The evaluation on the quality of teaching and learning is related to the level of students' satisfaction with the institutions of higher education. Better quality of teaching and learning produces a higher level of satisfaction, while poorer quality of teaching and learning will result in the lower level of the satisfaction of the students. The implication form this research is that a high level of satisfaction is in the hope of every customer of the service and administration provided by the university. Students' satisfaction results from the service and administration executed by the university. If the institution performs better service and administration, students will gain a high level of satisfaction as well as maintain their feelings of pride and loyalty to the university. Students' satisfaction also associates with their success in education. A high level of satisfaction in students will contribute to their success; conversely, the low level of satisfaction will be one of the factors leading to their failure.

\section{Conclusion}

Students' satisfactions with the quality of instruction, delivered by the lecturers were at the moderate level. Students possessed good perceptions of the task assignment and the evaluation done by the instructors. The quality of the lecturer's teaching had a positive relationship with students' satisfaction. This implies that the quality of teachers' instruction was one of the factors that could influence students' satisfaction. There were good 
relationships among the aspects of the lecturers' motivation, between the lecturers and the students, task assignment, examination, and evaluation, whereas the aspect of the lecturers' efficiency gave the largest contribution.

\section{References}

Aldridge, S., \& Rowely, J. (1998). Measuring customer satisfaction in higher education. Quality Assurance in Education, 6(4), 197-204. http://dx.doi.org/10.1108/09684889810242182

Barnard, J. (1999). Using total quality principles in business courses: The effect on student evaluations. Business Communication Quarterly, 62(2), 61-73. http://dx.doi.org/10.1177/108056999906200206

Chong, B. K., \& Crowther, F. (2005). A New framework for measuring the quality of outcomes-based engineering education. $35^{\text {th }}$ ASEE/IEEE Frontiers in Education Conference. http://dx.doi.org/10.1109/FIE.2005.1612017

DeShields Jr., O. W., Kara, A., \& Kaynak, E. (2005). Determinants of business student satisfaction and retention in higher education: applying Herzberg's two factor theory. International Journal of Educational Management, 19(2), 28-139. http://dx.doi.org/10.1108/09513540510582426

Elliott, K. M., \& Shin, D. (2002). Student satisfaction: an alternative approach to assessing this important concept. Journal of Higher Education Policy and Management, 24(2), 199-209. http://dx.doi.org/10.1080/1360080022000013518

Flinders University. (2001). International Course Work Student Satisfaction Survey. Adelaide, Australia.

Greiner, K. (2000). A Study of Academic Service Quality and Instructional Quality in a Midwestern Higher Education Environment. A Dissertation Presented to the School of Education Drake University. Retrieved from http:// www.lib.drake.edu.8080/dspace/bitstream/2092/297/1/

Greiner, K. (2000). A study of academic service quality and instructional quality in a Midwestern higher education environment. A Dissertation presented to the School of Education Drake University.

Gursoy, D., \& Umbreit, W. T. (2005, February). Exploring students' evaluations of teaching effectiveness: what factors are important? Journal of Hospitality \& Tourism Research, 29(1), 91-109. http://dx.doi.org/10.1177/1096348004268197

Handoyo, S. (2006). Beberapa Faktordari Mutu Layanan Akademik dan Pengajaran Yang Mempengaruhi Kepuasan Mahasiswa UNINUS Bandung, Tesis Magister Manajemen Pendidikan Program Pascasarjana Universitas Islam Nusantara Bandung.

Harvey, L. (1993). Quality assessment in higher education: Collected papers of the QHE project. Birmingham, QHE.

Hennig, T., Langer, M. F., \& Hansen, U. (2001, May). Modeling and managing student loyalty. Journal of Service Research, 3(4), 331-344. http://dx.doi.org/10.1177/109467050134006

Hennig-Thurau, T., \& Klee, A. (1997). The Impact of customer satisfaction and relationship quality on customer retention: A critical reassessment and model development. Journal Psychology \& Marketing, 14(8), 737-764. http://dx.doi.org/10.1002/(SICI)1520-6793(199712)14:8<737::AID-MAR2>3.0.CO;2-F

Hill, F. M. (1995). Managing service quality in higher education: the role of the student as primary consumer. Quality Assurance in Education, 3(3), 10-21. http://dx.doi.org/10.1108/09684889510093497

Holford, D., \& Patkar, A. (2003). Identification of service quality dimensions of pharmaceutical education. American Journal of Pharmaceutical Education, 67(4). Retrieved from http://www.ajpe.org/aj6704/aj6704108/aj6704108.pdf

Kara, A. (2004). Business student satisfaction, intentions and retention in higher education: An empirical investigation. Pennsylvania State University-York Campus Oscar W. DeShields, Jr., California State University, Northridge.

Leedy, P. D., \& Ormod, J. E. (2001). Practical research planning and design, Ed. Ke-7. Upper Saddle River, New York: Prenctice-Hall, Inc.

Marsh, H. W., \& Bailey, M. (1993). Multidimensional students' evaluations of teaching effectiveness. Journal of Higher Education, 64(1), 1-18. http://dx.doi.org/10.2307/2959975

Marsh, H. W., \& Hocevar, D. (1990). The Multidimensionality of students' evaluation of teaching effectiveness: The generality of factor structures across academic discipline, instructor level, and course level. Retrieved from http://www.mcmaster.ca/stlhl/documents/student $\% 20$ Evaluation $\% 20$ of $\% 20$ Teaching.pdf 
Marsh, H. W., \& Roche, L. (1993). The use of students' evaluations and an individually structured intervention to enhance university teaching effectiveness. American Educational Research Journal, 30(1), 217-251. http://dx.doi.org/10.3102/00028312030001217

Marsh, H. W., \& Roche, L. A. (1992). The use of student evaluations of university teaching in different settings: The applicability paradigm. Australia Journal of Education, 36(3), 278-300. http://dx.doi.org/10.1177/000494419203600305

Marsh, H.W. (1987). Students' evaluations of university teaching: Research findings, methodological issues and directions for future research. International Journal of Educational Research, 11, 252-388. http://dx.doi.org/10.1016/0883-0355(87)90001-2

MohdMajid, K. (2000). Kaedah penyelidikan pendidikan. Dewan Bahasa dan Pustaka. Kuala Lumpur.

Oxford Brookes Universiti. (2005). Student satisfaction survey. Centre for research and evaluation. Sheffield Hallam Universiti.

Palacio, A. B., Menesses, G. D., \& Perez, P. J. (2002). The configuration of the university image and its relationship with the satisfaction of students. Journal of Educational Administration, 40(5), 486-505. http://dx.doi.org/10.1108/09578230210440311

Ramsden, P. (1991). A performance indicator of teaching quality in higher education. Studies in Higher Education, 16(2), 129-150. http://dx.doi.org/10.1080/03075079112331382944

RobiahSidin (2000). Inovasi kaedah pengajaran: pengalaman di Universiti Kebangsaan Malaysia. Prosiding National Conference on Teaching and Learning in Higher Education, Oktober 9- 10, Universiti Utara Malaysia.

Rowley, J. (1996). Measuring quality in higher education. Quality in Higher Education, 2(3), 237-255. http://dx.doi.org/10.1080/1353832960020306

SaedahSiraj. (2000). Perkembangan Kurikulum. Edisi Pertama. Kuala Lumpur: AlamPintar Enterprise.

SevgiOzgungor. (2009). The relationships between students evaluations of teaching behaviours and self efficacy beliefs. Pamukkale Universiti. Department of Education, Educational Sciences. Denizili, 20020, Turkey, Procedia Social and Behavioral Sciences I (2009) 2687-2691.

Srinadi, I. G. A. M., \& Nilakusmawati, D. P. E. (2008). Faktor-Faktor Penentu Kepuasan Mahasiswa Terhadap Pelayanan Fakultas Sebagai Lembaga Pendidikan (StudiKasus Di Fmipa, Universitas Udayana). FMIPA Universitas Udayana. Bali

Stringer, M., \& Finlay, C. (1993).Assuring quality through student evaluation. In R. Ellis (Ed.), Quality assurance for university teaching. Milton Keynes: Open University Press.

Stringer, M., \& Irwing, P. (1998). Students' evaluations of teaching effectiveness: A structural modeling approach. British Journal of Educational Psychology, 68, 409-426. http://dx.doi.org/10.1111/j.2044-8279.1998.tb01301.x

Suardanan, I. M. (2007, April). Analisis Kepuasan mahasisiwa terhadap pelayan anjasa pendidikan pada sekolah tinggi ilmu ekonomi (STIE AMM) Mataram. Jurnal Valid, 4(I), 57-69.

Toland, M. D., \& De Ayala, R. J. (2005, April). Validity Studies: A Multilevel factor analysis of students' evaluations of teaching. Lincoln, Educational and Psychological Measurement, 65(2), 272-296. http://dx.doi.org/10.1177/0013164404268667

Wiers-Jenssen, J., Stensaker, B., \& Grogaard, J. B. (2002). Student satisfaction: towards an empirical deconstruction of the concept. Quality in Higher Education, 8(2), 183-195. http://dx.doi.org/10.1080/1353832022000004377

Wilkie, W. L. (1994). Consumer Behavior (3rd ed.). New York: Jhon Wiley \& Sons Inc.

Zulkiflee, O. (2002). Persepsidan Sikap Pelajar Terhadap Pelaksanaan Pengajarandan Pembelajaran Pendidikan Jasmani dan Kesihatan (PJK) di Sekolah-Sekolah Menengah Zon Bangsar, Kuala Lumpur. Masters thesis, Universiti Utara Malaysia.

\section{Copyrights}

Copyright for this article is retained by the author(s), with first publication rights granted to the journal.

This is an open-access article distributed under the terms and conditions of the Creative Commons Attribution license (http://creativecommons.org/licenses/by/3.0/). 